\title{
Thermostable Peroxidase from Bacillus stearothermophilus
}

\author{
By SUVIT LOPRASERT, SEIJI NEGORO* AND HIROSUKE OKADA \\ Department of Fermentation Technology, Osaka University, Yamada-oka, Suita-shi, \\ Osaka 565, Japan
}

(Received 5 October 1987; revised 29 January 1988)

\begin{abstract}
A peroxidase from Bacillus stearothermophilus was purified to homogeneity. The enzyme $\left(M_{\mathrm{r}}\right.$ 175000) was composed of two subunits of equal size, and showed a Soret band at $406 \mathrm{~nm}$. On reduction with sodium dithionite, absorption at $434 \mathrm{~nm}$ and $558 \mathrm{~nm}$ was observed. The spectrum of reduced pyridine haemochrome showed peaks at 418,526 and $557 \mathrm{~nm}$; the reduced minus oxidized spectrum of pyridine haemochrome showed peaks of 418,524 and $556 \mathrm{~nm}$ with a trough at $452 \mathrm{~nm}$. These results indicate that the enzyme contained protohaem IX as a prosthetic group. The optimum pH was about 6 and the apparent optimum temperature was $70^{\circ} \mathrm{C}$. The enzyme was relatively stable up to $70^{\circ} \mathrm{C}$; at $30^{\circ} \mathrm{C}$ it was stable for a month. The enzyme had peroxidase activity toward a mixture of 2,4-dichlorophenol and 4-aminoantipyrine with a $K_{\mathrm{m}}$ for $\mathrm{H}_{2} \mathrm{O}_{2}$ of $1.3 \mathrm{mM}$. It also acted as a catalase with a $K_{\mathrm{m}}$ for $\mathrm{H}_{2} \mathrm{O}_{2}$ of $7.5 \mathrm{mM}$.
\end{abstract}

\section{INTRODUCTION}

Peroxidases are important enzymes; widely used in the clinical field for the colorimetric measurement of biological materials. Peroxidases catalyse the oxidation of a large number of aromatic compounds such as phenol, hydroquinones and hydroquinoid amines, especially benzidine derivatives. Typical peroxidases are haemoproteins and occur in animals, plants, fungi and bacteria. The longest known and best studied peroxidase is horseradish peroxidase (Welinder, 1979), but bacterial peroxidases have attracted comparatively little attention.

So far, microbial peroxidases from Pseudomonas fluorescens (cytochrome $c$ peroxidase) (Lenhoff \& Kaplan, 1956), Streptococcus faecalis (NADH peroxidase) (Dolin, 1957), Escherichia coli (o-dianisidine peroxidase, HP-I) (Claiborne \& Fridovich, 1979), Halobacterium halobium (Fukumori et al., 1985), Rhodopseudomonas capsulata (Hochman \& Shemesh, 1987), Pellicularia filamentosa (Ichikawa et al., 1981), and Saccharomyces cerevisiae (cytochrome $c$ peroxidase) (Finzel et al., 1984) have been isolated, but there is little information about peroxidases from thermophilic bacteria. Obviously, a thermostable enzyme will provide us with important information about thermal resistance in catalase-peroxidase and will be suitable for practical purposes. In this study, the thermostable peroxidase from a thermophilic bacterium, Bacillus stearothermophilus, was purified and some of its characteristics were studied.

\section{METHODS}

Cell culture. B. stearothermophilus IAM 11001 (ATCC 8005) was grown in LB (Luria-Bertani) broth containing $\left(1^{-1}\right) 10 \mathrm{~g}$ tryptone, $5 \mathrm{~g}$ yeast extract and $10 \mathrm{~g} \mathrm{NaCl}, \mathrm{pH} 7 \cdot 3$. A loopful of stock culture was inoculated into $100 \mathrm{ml} \mathrm{LB}$ broth and incubated at $55^{\circ} \mathrm{C}$ with shaking for $12 \mathrm{~h}$. Part of this culture was transferred to 61 of medium $(1 \%$ inoculum) and incubated under the same conditions for $18 \mathrm{~h}$.

Purification of peroxidase. All the purification steps were done at room temperature unless otherwise indicated. Cells from 61 of culture were harvested by centrifugation $(3000 \mathrm{~g}, 10 \mathrm{~min}$ ), suspended in $200 \mathrm{ml} 100 \mathrm{~mm}$ sodium/potassium phosphate buffer, $\mathrm{pH} \mathrm{7,} \mathrm{and} \mathrm{disrupted} \mathrm{by} \mathrm{sonication} \mathrm{at} 20 \mathrm{kHz}$ for $10 \mathrm{~min}$. The lysate was centrifuged at $3000 \mathrm{~g}$ for $10 \mathrm{~min}$. Solid ammonium sulphate was added to $180 \mathrm{ml}$ of the supernatant to $35 \%$ saturation; the supernatant was then centrifuged at $8000 \mathrm{~g}$ for $10 \mathrm{~min}$. Ammonium sulphate was further added to 
$55 \%$ saturation and the resulting precipitate was collected by centrifugation under the same conditions. The precipitate was dissolved in $65 \mathrm{ml} 20 \mathrm{~mm}$-sodium/potassium phosphate buffer, $\mathrm{pH} 7$, and dialysed against the same buffer for $18 \mathrm{~h}$ at $4{ }^{\circ} \mathrm{C}$. The dialysed enzyme was put onto a DEAE-Sephadex A50 column $(5.8 \times 60 \mathrm{~cm})$, which had been equilibrated with $20 \mathrm{mM}$-phosphate buffer, $\mathrm{pH} 7$, and eluted with 21 of a 0 to $0.5 \mathrm{M}-\mathrm{NaCl}$ linear gradient in phosphate buffer. Fractions containing peroxidase activity were pooled, concentrated by ultrafiltration, and put on a second DEAE-Sephadex A50 column; the enzyme was then eluted in the same manner. The enzyme fractions were pooled, concentrated by ultrafiltration, adjusted to $4 \%$ saturation with ammonium sulphate, and adsorbed on a column $(2.6 \times 60 \mathrm{~cm})$ of Phenyl-Sepharose CL-4B, which had been equilibrated with $20 \mathrm{mM}$ phosphate buffer, $\mathrm{pH} 7$, containing $4 \%$ saturation ammonium sulphate. The peroxidase activity was then eluted with 21 of a decreasing linear gradient of ammonium sulphate (3.75 to $0.9 \%$ in phosphate buffer). Fractions containing peroxidase activity were pooled, concentrated to $2 \mathrm{ml}$, and put onto a column $(2.5 \times 70 \mathrm{~cm})$ of Sephadex G-200 previously equilibrated with $20 \mathrm{~mm}$-phosphate buffer, pH 7). Fractions showing high specific enzyme activity were pooled and further purified by HPLC on a DEAE-5PW column equilibrated with $20 \mathrm{mM}-$ phosphate buffer, $\mathrm{pH} 7$, and eluted with a 0 to $0.5 \mathrm{M}-\mathrm{NaCl}$ linear gradient in the same buffer.

Peroxidase assay. Enzyme activity was measured using 2,4-dichlorophenol/4-aminoantipyrine as substrates (Emerson, 1943). The enzyme $(10 \mu \mathrm{l})$ was added to $3 \mathrm{ml}$ of a substrate mixture containing $4 \cdot 1 \mathrm{~mm}-2,4-$ dichlorophenol, 0.67 mM-4-aminoantipyrine, $2.9 \mathrm{mM}-\mathrm{H}_{2} \mathrm{O}_{2}$ and $33 \mathrm{~mm}$-sodium/potassium phosphate buffer, $\mathrm{pH} 6$. The activity was assayed using a Hitachi $220 \mathrm{~A}$ spectrophotometer with a thermostatted cell compartment at $50{ }^{\circ} \mathrm{C}$. The increase in absorbance at $500 \mathrm{~nm}$ was continuously recorded and the catalytic activity was calculated using $\varepsilon_{500}=1.36 \times 10^{4} 1 \mathrm{~mol}^{-1} \mathrm{~cm}^{-1}$ (Tamaoku et al., 1982).

Catalase assay. Catalase was assayed spectrophotometrically by measuring the decrease in absorbance at $240 \mathrm{~nm}$ as described by Aebi (1983), using $\varepsilon_{240}=43.61 \mathrm{~mol}^{-1} \mathrm{~cm}^{-1}$ (Hildebrandt \& Roots, 1975).

Protein concentration. This was determined from the absorbance at $280 \mathrm{~nm}$.

Gel electrophoresis. Electrophoresis on $7.5 \%(\mathrm{w} / \mathrm{v})$ polyacrylamide gels was done as described by Davis (1964). After electrophoresis, protein was stained with Coomassie Brilliant Blue R250. Peroxidase activity was detected by incubating the gel at room temperature with $10 \mathrm{mM}$-sodium/potassium phosphate buffer ( $\mathrm{pH} 6$ ) containing 40 mM-pyrogallol and $7 \cdot 4 \mathrm{mM}-\mathrm{H}_{2} \mathrm{O}_{2}$ for $3 \mathrm{~min}$. The catalase band was detected as described by Gregory \& Fridovich (1974), but pyrogallol was used instead of diaminobenzidine. SDS-PAGE in a $10 \%$ gel was done according to Weber \& Osborn (1969).

$M_{r}$ measurements. These were done by HPLC (TSK-G3000SW column) using the following proteins as standards : cytochrome $c(12400)$, adenylate kinase (32000), enolase (67000), lactate dehydrogenase (142000) and glutamate dehydrogenase (290000). The subunit $M_{\mathrm{r}}$ was measured by SDS-PAGE with the following standard proteins: phosphorylase b (94000), bovine serum albumin (67000), ovalbumin (43000), carbonic anhydrase (30000), soy bean trypsin inhibitor (20000) and $\alpha$-lactalbumin (14400).

Spectroscopy. Absorbance was recorded using a Hitachi $220 \mathrm{~A}$ spectrophotometer. The native enzyme was scanned from 250 to $700 \mathrm{~nm}$, reduced by adding $1 \mathrm{mg}$ sodium dithionite, and then scanned again. Haem was measured as the pyridine haemochromogen as described by Falk (1964a).

Chemicals. DEAE-Sephadex, Phenyl-Sepharose CL-48 and Sephadex G-200 were obtained from Pharmacia. 2,4-Dichlorophenol, guaiacol and $\mathrm{H}_{2} \mathrm{O}_{2}$ peroxide were from Nakarai (Japan). 4-Aminoantipyrine, catechol, pyrogallol, pyridine and sodium dithionite were from Wako (Japan).

\section{RESULTS AND DISCUSSION}

Purification. Cell-free extract from a 61 culture of $B$. stearothermophilus IAM 11001 was processed by ammonium sulphate fractionation and separation and through a series of chromatography columns as indicated in Table 1 . The enzyme was purified 120 -fold from the crude extract to a specific activity of 18 units (mg protein $)^{-1}$ with $10 \%$ recovery of activity. The absorption coefficient $\left(A_{280 \mathrm{~nm}}^{1 \%}\right)$ of the lyophilized enzyme was $16 \cdot 2$.

Homogeneity. The purified enzyme preparation moved as a single protein component in PAGE; it had both peroxidase and catalase activity (Fig. 1). Peroxidases from E. coli (HP-I) (Claiborne \& Fridovich, 1979), H. halobium (Fukumori et al., 1985) and $R$. capsulata (Hochman $\&$ Shemesh, 1987) also had both peroxidase and catalase activity. The $M_{\mathrm{r}}$ of the enzyme was 175000 by HPLC but only 86000 by SDS-PAGE, indicating that the peroxidase is a dimer consisting of two homologous subunits, with a subunit $M_{\mathrm{r}}$ similar to that of $E$. coli peroxidase. However, E. coli peroxidase is a tetramer. The catalase from Comamonas compransor, which also shows peroxidase activity, has been reported to be a dimer composed of two identical subunits of $M_{\mathrm{r}} 75000$ (Nies \& Schlegel, 1982). 
(a)

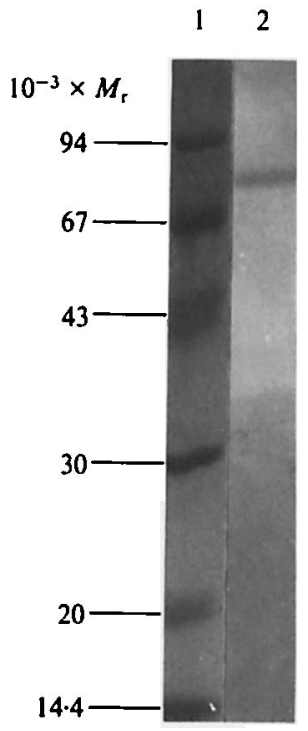

(b)

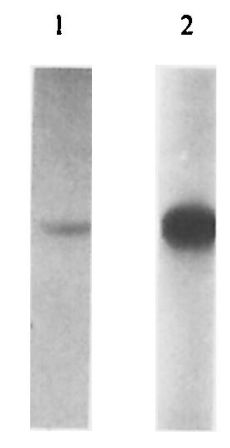

Fig. 1. PAGE of purified peroxidase. (a) SDS polyacrylamide $(10 \%, \mathrm{w} / \mathrm{v})$ gel. Lane $1, M_{\mathrm{r}}$ marker proteins; lane 2, purified peroxidase. (b) Polyacrylamide (non-denatured) $(7.5 \%, \mathrm{w} / \mathrm{v})$ gel. Lane 1 , protein staining with Coomassie Brilliant Blue; lane 2, activity staining for peroxidase with pyrogallol. Details are described in Methods.

Table 1. Purification of peroxidase from B. stearothermophilus

\begin{tabular}{lcccc}
\multicolumn{1}{c}{ Step } & $\begin{array}{c}\text { Total protein } \\
\text { (mg) }\end{array}$ & $\begin{array}{c}\text { Total activity } \\
\text { (units) }\end{array}$ & $\begin{array}{c}\text { Specific activity } \\
\text { [units (mg protein) }\end{array}$ & $\begin{array}{c}\text { Yield } \\
(\%)\end{array}$ \\
Crude extract & 4100 & 610 & 0.15 & 100 \\
Ammonium sulphate & 2700 & 480 & $0 \cdot 18$ & 79 \\
DEAE-Sephadex A-50(I) & 260 & 440 & $1 \cdot 6$ & 72 \\
DEAE-Sephadex A-50(II) & 170 & 400 & $2 \cdot 3$ & 66 \\
Phenyl-Sepharose CL-4B & 40 & 360 & $9 \cdot 9$ & 59 \\
Sephadex G-200 & 7 & 120 & $17 \cdot 1$ & 20 \\
HPLC-DEAE-5PW & $3 \cdot 3$ & 58 & $17 \cdot 7$ & 10
\end{tabular}

Substrate specificity. Various kinds of hydrogen donors were examined as potential substrates for the peroxidase (Table 2). A mixture of 4-aminoantipyrine and 2,4-dichlorophenol was the best substrate giving the highest enzyme activity; also, the reaction product had the highest absorption peak at $512 \mathrm{~nm}$. 2,4-Dichlorophenol was a better hydrogen donor than phenol, giving three times higher activity. The derivatives of phenol also gave a higher colour intensity than phenol in a study of peroxidase from the fungus Arthromyces ramosus (Shinmen et al., 1986). The peroxidase from $B$. stearothermophilus was highly specific for a mixture of 4-aminoantipyrine and 2,4-dichlorophenol (or phenol) among the substrates examined. The activity towards $o$ aminophenol and pyrogallol was low, and activity was negligible towards catechol and guaiacol: this is similar to the substrate specificity of Pellicularia filamentosa peroxidase (Ichikawa et al., 1981). Haemoprotein $b-590$ from $E$. coli, which has a close structural and functional relationship to HP-I, a cytochrome $a_{1} b$ preparation (Poole $e t$ al., 1986) and the catalase-peroxidase from $R$. capsulata (Hochman \& Shemesh, 1987) also showed no detectable peroxidase activity toward guaiacol. 


\section{Table 2. Substrate specificity of peroxidase from B. stearothermophilus}

For substrates 1 and 2, conditions were as described in the Methods. For substrates 3 to 6, the concentration of substrate in the reaction mixture was $0.7 \mathrm{mM}$; absorbance measured at $500 \mathrm{~nm}$ for 1 and 2, $480 \mathrm{~nm}$ for 3 and $5,420 \mathrm{~nm}$ for 4 , and $430 \mathrm{~nm}$ for 6 . Increases in absorbance in 1 min were compared and expressed as relative activity. For dichlorophenol + aminoantipyrine $100 \%$ relative activity was $18.6 \mu \mathrm{mol} \mathrm{min} \mathrm{mi}^{-1} \mathrm{ml}^{-1}$.

\section{Substrate}

1 Dichlorophenol + aminoantipyrine

2 Phenol + aminoantipyrine

3 o-Aminophenol

4 Pyrogallol

5 Catechol

6 Guaiacol

Relative activity $(\%)$
100
37
1.6
1.3
0
0

pH optimum. The peroxidase had an optimum $\mathrm{pH}$ at 6.0 both in acetate and in phosphate buffers. At $\mathrm{pH} 5.5$ to 6.5 , the enzyme was highly active, but at $\mathrm{pH}$ values higher than 7 or lower than 5 , activity decreased. Imidazole at concentrations from 10 to $50 \mathrm{mM}$ enhanced the peroxidase activity by about $40 \%$, which is similar to the effect of imidazole on the enzyme from C. compransoris (Nies \& Schlegel, 1982).

Optimum temperature and stability. The apparent optimum temperature for the peroxidase activity was $70^{\circ} \mathrm{C}$. To check the thermostability of the enzyme, it was incubated in $100 \mathrm{~mm}$ sodium/potassium phosphate buffer, $\mathrm{pH} \mathrm{6}$, for $10 \mathrm{~min}$ at various temperatures. Activity was then assayed and expressed as a percentage of the activity of the untreated sample. The peroxidase retained $80 \%$ activity after incubation at $70{ }^{\circ} \mathrm{C}$. In contrast, catalase-peroxidase from a mesophile (E. coli) and from a photosynthetic bacterium ( $R$. capsulata) lost all activity after $5 \mathrm{~min}$ at $60^{\circ} \mathrm{C}$ (Nadler et al., 1986).

As the enzyme was thermostable, it might be expected to be stable at lower temperatures. Peroxidase in $100 \mathrm{~mm}$-sodium/potassium phosphate buffer, $\mathrm{pH} 7$, plus $10 \%$ (v/v) glycerol was incubated at $30{ }^{\circ} \mathrm{C}$. For the first $2 \mathrm{~d}$ the enzyme retained $100 \%$ activity; after 5 and $34 \mathrm{~d}$ it still retained $81 \%$ and $67 \%$ respectively, of its original activity. This high stability enabled purification to be done at room temperature and facilitated the study and storage of the enzyme. It is clearly different from horseradish peroxidase, which loses about $10 \%$ of its activity per day at $20^{\circ} \mathrm{C}$ (Putter \& Becker, 1983), or peroxidase from $H$. halobium which has to be kept at a high salt concentration (Fukumori et al., 1985).

Optical spectra and haem content. The absorbance spectrum of the native enzyme had a Soret band at $406 \mathrm{~nm}$ (Fig. 2a). After reducing the enzyme with sodium dithionite, the Soret band was observed at $434 \mathrm{~nm}$; a small peak at $558 \mathrm{~nm}$ appeared also (Fig. $2 a$ ). The Soret band indicated that the peroxidase contains haem. To identify the type of haem, pyridine haemochrome was examined. When the enzyme was reduced in alkaline pyridine, it yielded a haemochromogen whose spectrum was identical with that of protohaem IX. The spectrum of reduced pyridine haemochrome showed peaks at 418,526 and $557 \mathrm{~nm}$ (Fig. $2 b$ ). The pattern of reduced minus oxidized pyridine haemochrome showed peaks at 418,524 and $556 \mathrm{~nm}$ with a trough at $452 \mathrm{~nm}$ (Fig. 2b). The protohaem content was estimated from the spectrum of its pyridine haemochromogen using $\varepsilon_{418.5}=1.92 \times 10^{5} 1 \mathrm{~mol}^{-1} \mathrm{~cm}^{-1}$ (Falk, 1964b). On this basis we assume that there is one molecule of protohaem IX per dimer of peroxidase. This low haem content is consistent with an $A_{406} / A_{280}$ ratio of 0.35 . However, the possibility still remains that haem molecules were lost during purification. Protohaem IX is the common type of haem found in peroxidases and catalases from micro-organisms such as Micrococcus luteus (Herbert \& Pinsent, 1948), Rhodopseudomonas sphaeroides (Clayton, 1959), S. cerevisiae (Finzel et al., 1984), C. compransoris (Nies \& Schlegel, 1982) and E. coli (Claiborne \& Fridovich, 1979).

Kinetics of the peroxidase reaction. The peroxidase from $B$. stearothermophilus had both peroxidase and catalase activity. For the peroxidatic activity with 2,4-dichlorophenol/4- 


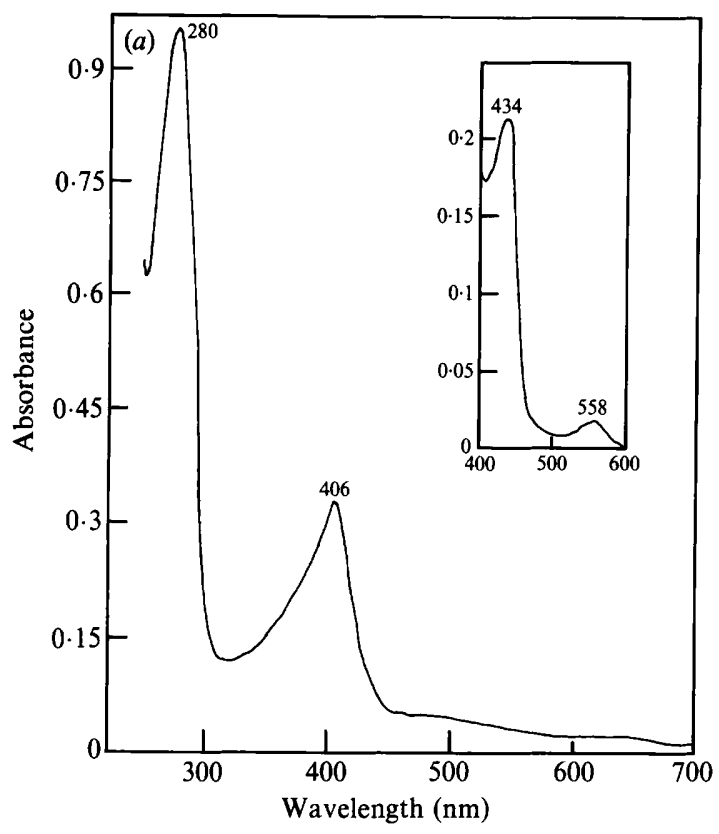

Fig. 2(a)

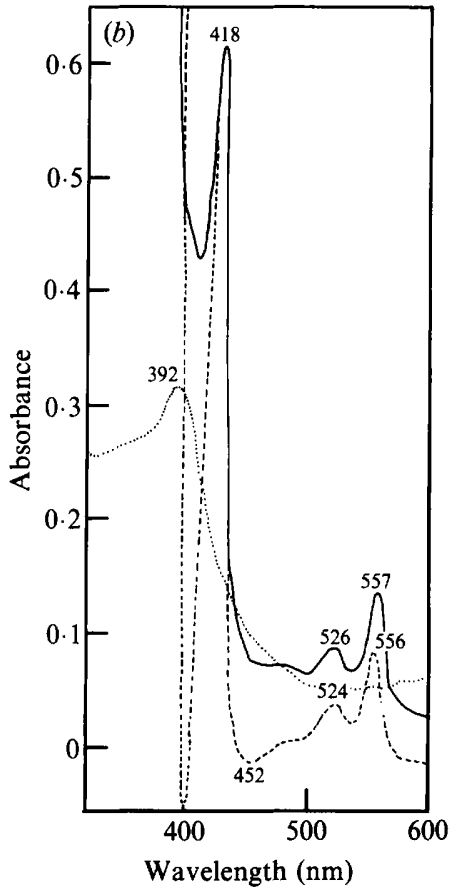

Fig. $2(b)$

Fig. 2. (a) Absorption spectra of peroxidase $(3 \mu \mathrm{M})$ in $20 \mathrm{mM}$-sodium/potassium phosphate buffer, $\mathrm{pH} 7$. (Inset, absorption spectrum of peroxidase reduced by sodium dithionite.) (b) Absorption spectra of pyridine haemchromogen derived from $4 \mu \mathrm{M}$-peroxidase). - - Reduced form; ; $\cdots$, oxidized form; ----, reduced minus oxidized.

aminoantipyrine as substrate, the $K_{\mathrm{m}}$ for $\mathrm{H}_{2} \mathrm{O}_{2}$ was $1.3 \mathrm{mM}$. Study of the peroxidase reaction was frustrated by the ability of the enzyme to act as a catalase and decompose the $\mathrm{H}_{2} \mathrm{O}_{2}$. Therefore, the $K_{\mathrm{m}}$ value would be lower than estimated as the actual concentration of $\mathrm{H}_{2} \mathrm{O}_{2}$ was reduced by decomposition. The $K_{\mathrm{m}}$ is higher than the value of $0.048 \mathrm{mM}$ for HP-I and/or II (Loewen \& Triggs, 1984) and the value of $0 \cdot 18 \mathrm{mM}$ for haemoprotein $b-590$ (Poole et al., 1986).

Kinetics of the catalase reaction. At $\mathrm{H}_{2} \mathrm{O}_{2}$ concentrations up to $40 \mathrm{mM}$, B. stearothermophilus hydroperoxidase was not rapidly inactivated and the initial linear rate of $\mathrm{H}_{2} \mathrm{O}_{2}$ decomposition was used to estimate $K_{\mathrm{m}}$ from a Lineweaver-Burk plot. The $K_{\mathrm{m}}$ was $7.5 \mathrm{mM}$, which is similar to the values for $C$. compransoris catalase (1.9 mM) (Nies \& Schlegel, 1982), E. coli HP-I (3.9 mM) (Claiborne \& Fridovich, 1979), E. coli catalase (4.1 mM) (Loewen \& Triggs, 1984), and E. coli haemoprotein $b-590$ (11 mM) (Poole et al., 1986).

In conclusion, the peroxidase from $B$. stearothermophilus acts as a hydroperoxidase or catalase-peroxidase enzyme, as implied by its name, that can catalyse both catalase and peroxidase reactions at significant rates. Peroxidase and catalase are enzymes that share a number of structural and physicochemical properties. The prosthetic group is haem, with the haem iron in the ferric high-spin state, which is able to bind fluoride, cyanide or azide (Paul, 1963; Brill, 1966).

There have been few reports of catalase-peroxidases in recent years. The catalase-peroxidase from B. stearothermophilus studied here is the first to be isolated from a thermophile. Study of this enzyme should provide significant information on the heat stability of catalase-peroxidase, its molecular mechanisms and a comparative study of its evolution. The enzyme should also be a good candidate for industrial applications. 


\section{REFERENCES}

AEBI, H. (1983). Catalase. In Methods of Enzymatic Analysis, vol. 3, 3rd edn, pp. 273-285. Edited by H. U. Bergmeyer. Weinheim: Verlag Chemie.

BrILl, A. S. (1966). Peroxidase and catalase. In Comprehensive Biochemistry, vol. 14, pp. 447-449. Edited by M. Florkin \& E. H. Stotz. Amsterdam: Elsevier.

Clatborne, A. \& Fridovich, I. (1979). Purification of the $o$-dianisidine peroxidase from Escherichia coli B. Physicochemical characterization and analysis of its dual catalatic and peroxidatic activities. Journal of Biological Chemistry 254, 4245-4252.

Clayton, R. K. (1959). Purified catalase from Rhodopseudomonas sphaeroides. Biochimica et biophysica acta 36, 40-47.

Davis, B. J. (1964). Disc electrophoresis II. Methods and application to human serum proteins. Annals of the New York Academy of Sciences 121, 404-408.

Dolin, M. I. (1957). Streptococcus faecelis oxidase for reduced diphosphopyridine nucleotide. Journal of Biological Chemistry 225, 557-573.

EMERSON, J. (1943). The condensation of aminoantipyrine II. A new color test for phenolic compounds. Journal of Organic Chemistry 8, 417-428.

FALK, J. E. (1964a). Porphyrins and Metalloporphyrins, pp. 181-182. New York: Elsevier.

FALK, J. E. (1964b). Porphyrins and Metalloporphyrins, pp. 240. New York: Elsevier.

Finzel, B. C., Poulos, T. L. \& Kraut, J. (1984). Crystal structure of yeast cytochrome $c$ peroxidase refined at $1 \cdot 7-\AA$ resolution. Journal of Biological Chemistry 259, 13027-13036.

FuKUmori, Y., FujiWara, T., OKUdA-Tahahashi, Y., Mukohata, Y. \& Yamanaka, T. (1985). Purification and properties of a peroxidase from Halobacterium halobium L-33. Journal of Biochemistry 98, 10551061.

Gregory, E. M. \& Fridovich, I. (1974). Visualization of catalase on acrylamide gels. Analytical Biochemistry 58, 57-62.

Herbert, D. \& Pinsent, J. (1948). Crystalline bacterial catalase. Biochemical Journal 43, 193-202.

HildebrandT, A. G. \& Roots, I. (1975). Reduced nicotinamide adenine dinucleotide phosphate (NADPH)-dependent formation and breakdown of hydrogen peroxide during mixed function oxidation reduction in liver microsomes. Archives of Biochemistry and Biophysics 171, 385-397.

Hochman, A. \& Shemesh, A. (1987). Purification and characterization of a catalase-peroxidase from the photosynthetic bacterium Rhodopseudomonas capsulata. Journal of Biological Chemistry 264, 6871-6876.

ICHIKAWA, K., OKAZAKI, K., Kimoto, K. \& WataNABE, Y. (1981). Partial purification of peroxidase from Pellicularia filamentosa. Agricultural and Biological Chemistry 45, 1297-1299.

LENHOFF, H. M. \& KAPLAN, N. O. (1956). A cytochrome peroxidase from Pseudomonas fluorescens. Journal of Biological Chemistry 220, 967-982.

Loewen, P. C. \& Triggs, B. L. (1984). Genetic mapping of $k a t F$, a new locus that with $k a t E$ affects the synthesis of a second catalase species in Escherichia coli. Journal of Bacteriology 160, 668-695.

Nadler, V., Goldberg, I. \& Hochman, A. (1986). Comparative study of bacterial catalases. Biochimica et biophysica acta 882, 234-241.

Nies, D. \& Schlegel, H. G. (1982). Catalase from Comamonas compransoris. Journal of General and Applied Microbiology 28, 311-319.

PAUL, K. G. (1963). Peroxidases. In The Enzyme, vol. 8, pp. 227-274. Edited by P. D. Boyer, H. A. Lardy \& K. Myrback. New York: Academic Press.

Poole, R. K., Baines, B. S. \& ApPleby, A. C. (1986). Haemoprotein $b-590$ (Escherichia coli), a reducible catalase and peroxidase: evidence for its close relationship to hydroperoxidase $I$ and cytochrome $\mathrm{a}_{1}$ b preparation. Journal of General Microbiology 132, $1525-1539$.

Putter, J. \& Becker, R. (1983). Peroxidases. In Methods of Enzymatic Analysis, vol. 3, 3rd edn, pp. 286-292. Edited by H. U. Bergmeyer. Weinheim: Verlag Chemie.

Shinmen, Y., Asami, S., Amachi, T., Shimizu, S. \& YamadA, H. (1986). Crystallization and characterization of an extracellular fungal peroxidase. Agricultural and Biological Chemistry 50, 247-249.

Tamaoku, K., Murao, Y., AKiURa, K. \& Ohkura, Y. (1982). New water soluble hydrogen donors for the enzymatic spectrophotometric determination of hydrogen peroxide. Analytica chimica acta 136, 121127.

WEBER, K. \& OSBORN (1969). The reliability of molecular weight determination by dodecyl sulfate polyacrylamide gel electrophoresis. Journal of Biological Chemistry 244, 4406-4409.

WELINDER, K. G. (1979). Amino acid sequence studies of horseradish peroxidase. European Journal of Biochemistry 96, 483-502. 